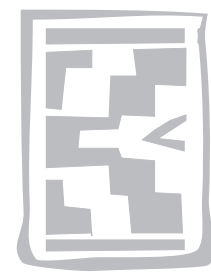

\title{
The testing and modification of a commercially available transport medium for the transportation of pure cultures of Haemophilus paragallinarum for serotyping
}

\author{
R.R. BRAGG ${ }^{1}$, P. JANSEN VAN RENSBURG, E. VAN HEERDEN and J. ALBERTYN \\ Department of Microbial, Biochemical and Food Biotechnology, University of the Free State \\ P.O. Box 339, Bloemfontein, 9300 South Africa
}

\begin{abstract}
BRAGG, R.R., JANSEN VAN RENSBURG, P., VAN HEERDEN, E. \& ALBERTYN, J. 2004. The testing and modification of a commercially available transport medium for the transportation of pure cultures of Haemophilus paragallinarum for serotyping. Onderstepoort Journal of Veterinary Research, 71:93-98

Haemophilus paragallinarum, the causative agent of infectious coryza in poultry, is an extremely fastidious organism requiring specific growth conditions for isolation. For complete control of the disease in regions where more that one of the serovars of the different serogroups occurs, it is essential that the bacterium causing the problem be isolated and serotyped. This work describes the modification and testing of transport media, which will ensure the survival of the causative agents in suspected infectious coryza cases for transport to a laboratory where the bacterium can be isolated and serotyped. The various transport media used are based on commercially available Amies Transport Medium supplemented with the different supplements used for the growth of $H$. paragallinarum. It was established that the bacterium remains viable for up to 18 days in Amies Transport Medium containing all the supplements when stored at $4^{\circ} \mathrm{C}$ or $37^{\circ} \mathrm{C}$. At room temperature or $25^{\circ} \mathrm{C}$, there was no difference in the survival of $H$. paragallinarum in commercial Amies Transport Medium (without charcoal) and Amies Transport Medium with supplements.
\end{abstract}

Keywords: Infectious coryza, Haemophilus paragallinarum, transport medium

\section{INTRODUCTION}

The bacterium, Haemophilus paragallinarum (Bibberstein \& White 1969) causes infectious coryza (IC), which is an upper respiratory tract infection in chickens, both layers and breeders. The NADdependent strains of $H$. paragallinarum are very fastidious organisms requiring two supplements to the medium which are essential for their growth. These are NAD at $1.56-25 \mu \mathrm{g} / \mathrm{m} \ell$ of medium (Page 1962) and between 1.0-1.5\% NaCl (Rimler, Davies \& Page 1977). Chicken serum has also been found to be required by most pathogenic strains (Sawata,

\footnotetext{
1 E-mail: braggrr.sci@mail.uovs.ac.za

Accepted for publication 23 October 2003-Editor
}

Kume \& Nakase 1980), while other isolates have been reported as showing better growth in the presence of $1 \%$ chicken serum ( Blackall \& Reid 1982; Hinz 1973).

It has been demonstrated that there are three serogroups of $H$. paragallinarum (Page 1962; Kume, Sawata, Nakase \& Matsumoto 1983; Blackall, Eavers \& Rogers 1990a ) consisting of at least nine different serovars (Blackall, Eavers \& Aus 1990b) and that the protection afforded by a vaccine is determined by the serovars of the bacterium present in the vaccine (Rimler et al. 1977; Kume, Sawata \& Nakase 1980)

The development of a PCR test which is specific for $H$. paragallinarum (Chen, Miflin, Zhang \& Blackall 
1996) has greatly assisted in the diagnosis of IC, particularly in regions where the poultry production facilities are far removed from diagnostic laboratories. Miflin, Chen, Bragg, Welgemoed, Greyling, Horner \& Blackall (1999) demonstrated that the PCR test established by Chen et al. (1996) was specific for both the NAD-dependent and NADindependent isolates. They also demonstrated that it could differentiate between $H$. paragallinarum and other closely related organisms which can be isolated from the sinuses of chickens. Unfortunately this test is not serogroup or serovar specific.

Serotyping of isolates from regions where there have been vaccination failures remains essential and in order to achieve this, the causative bacterium must be isolated and serotyped. Infectious coryza remains a serious problem in many developing countries where technical facilities for the serotyping of isolates are often not available and in order to achieve this they must be transported to betterequipped laboratories. In addition, many of the laboratories that lack the facilities to perform serotyping also lack those to freeze-dry isolates. This makes the transport of isolates from developing countries very difficult.

Currently, there is no suitable transport medium for the long distance transport of $H$. paragallinarum. Transport media for Neisseria gonorrhoeae, which is also an extremely fastidious organism are, however available. This organism can be transported successfully in Amies Transport Medium with or without the addition of charcoal.

There are many similarities in the growth requirements of $N$. gonorrhoeae and those of $H$. paragallinarum, such as their micro-aerophilic nature and the fact that both organisms show improved growth in the presence of serum. In the light of these similarities, attempts were made to establish a transport medium for $H$. paragallinarum, based on that for N. gonorrhoeae.

\section{MATERIALS AND METHODS}

A sample of the Modesto strain of $H$. paragallinarum, which is a serogroup C isolate (serovar C-2) was obtained from the Faculty of Veterinary Science, University of Pretoria as a freeze-dried culture. This bacterium was reconstituted on TMB broth (Reid \& Blackall 1984) and was stored by freeze-drying or in MicroBank ${ }^{\mathrm{TM}}$ at $-70^{\circ} \mathrm{C}$.

The identity of the bacterium as $H$. paragallinarum was tested using the PCR test developed by Chen et al. (1996) without any modifications. The purity of the culture was established by plating the bacterium onto blood tryptose agar (BTA) plates together with a feeder culture of Staphylococcus aureus, and observation of typical satellitism (De Blieck 1932). These tests were also used to confirm the identity and purity of all samples stored on the different transport media developed and tested in these experiments.

Eight different variations on Amies Transport Medium were evaluated for the transport of $H$. paragallinarum (Table 1). These variations include commercially available Amies Transport swabs or media (tubes) with or without charcoal; (abbreviated as $\mathrm{A} / \mathrm{TS}, \mathrm{A} / \mathrm{Wc}$ and $\mathrm{A} / \mathrm{-c}$ respectively). In addition, four different supplements were added to Amies Transport Medium to determine if any of these supplements has as effect on the viability of $H$. paragallinarum.

Amies Transport Medium with charcoal (A/Wc) and without charcoal $(A /-c)$ were prepared in sterile petri dishes. The plates were inoculated with pure cultures of $H$. paragallinarum and incubated at $37^{\circ} \mathrm{C}$ for 4 days, after which viability of each culture was tested by taking samples from which were plated onto BTA plates with a feeder culture of Staphylococcus aureus. The identity of each sample showing positive growth was confirmed through PCR.

Amies Transport swabs (A/Ts) without charcoal were tested for their suitability for transporting pure cultures of $H$. paragallinarum at four different temperatures. Sixty four swabs were made from $18 \mathrm{~h}$ old cultures of $H$. paragallinarum growing on BTA plates, containing a feeder culture. Sixteen of these swabs were stored at $4{ }^{\circ} \mathrm{C}, 16$ were kept at room temperature (which ranged from between $21^{\circ} \mathrm{C}$ to $28^{\circ} \mathrm{C}$ during the course of these experiments), 16 were incubated at $25^{\circ} \mathrm{C}$ and the remaining 16 were incubated at $37^{\circ} \mathrm{C}$.

Two of the swabs were selected each day from the $4^{\text {th }}$ day of storage from each of the four groups and were plated out onto BTA plates with a feeder culture of $S$. aureus. Five of the colonies were randomly selected for confirmation of identify of the isolated bacterium by the PCR test.

One hundred and twenty eight samples of $H$. paragallinarum growing on BTA plates were collected on sterile swabs which were then placed into tubes containing different versions of the transport medium (A/NAD, A/T, A/A-O, A/serum and A/supp; Table 1). The tubes were divided into four groups of 32 samples each and each group was maintained at 
$4{ }^{\circ} \mathrm{C}, 25^{\circ} \mathrm{C}, 37^{\circ} \mathrm{C}$ or at room temperature. Two samples were removed daily from the $4^{\text {th }}$ day of incubation for a total of 19 days and the swabs were processed to determine survival of the sample.

Twelve swabs were used to collect samples from the sinuses of broiler breeders suffering from IC on a farm in Zimbabwe. After collection the swabs were placed into tubes containing Amies Transport Medium. Another four swabs were collected from the drinking water in sheds where clinically infected broiler breeders were housed. All of these swabs were transported to Johannesburg International Airport from Harare, Zimbabwe as hand luggage, followed by further transportation by car to Bloemfontein where they were processed by plating them out onto BTA plates with a feeder culture. Identity of the bacterial colonies was confirmed as $H$. paragallinarum by PCR. The total time elapsed from collection of the samples to processing in the laboratory was 5 days.

Samples of pure cultures of $H$. paragallinarum were collected from BTA plates on sterile swabs which were placed into tubes containing one of the following modified transport media: swabs, A/NAD, A/T, A/A-O, A/serum and A/Supp (Table 1). These samples were sent by airmail post to Cape Town, after which they were returned to the laboratory in Bloemfontein and processed as described above. The total time spent in transit was 6 days.

\section{RESULTS AND DISCUSSION}

The results obtained when samples of $H$. paragallinarum were stored at different temperatures in Amies Transport Medium with (A/Wc) and without charcoal $(\mathrm{A} / \mathrm{C})$ are in Table 2. From the results obtained it was established that $H$. paragallinarum survived better on Amies Transport Medium without charcoal. All further experiments were therefore conducted in the absence of charcoal.

The survival of $H$. paragallinarum in Amies Transport swabs without charcoal at different temperatures for various days was tested (Table 3 ).

Viable bacteria could be isolated after 9 days in Amies Transport Medium kept at $4^{\circ} \mathrm{C}$ and $37^{\circ} \mathrm{C}$. At $25^{\circ} \mathrm{C}$ and room temperature viable bacteria could be isolated for up to 8 days of storage.

To explore the possibility of further enhancing the viability of isolates during transport, Amies Transport Medium without charcoal was supplemented with different combinations of the supplements required by $H$. paragallinarum for growth (A/NAD, A/T, A/A-O, $A$ serum and $A$ /supp; Table 1). These media were tested through inoculation with $H$. paragallinarum and subsequent storage at four different temperatures. A comparison of the maximum survival time can be seen in Table 4.

With storage at $4^{\circ} \mathrm{C}$, the best results were obtained in the medium that received the full compliment of supplements. It was found that viable bacteria could be recovered after a total of 18 days. Viable bacteria could be found in all of the media tested for at least 15 days at $4^{\circ} \mathrm{C}$. With storage at $25^{\circ} \mathrm{C}$ the best results were obtained in the medium with the full group of supplements. However, the duration of survival was greatly reduced with viable bacteria only isolated from samples stored for up to 7 days. This is in sharp contrast to the survival of the bacteria for 18 days in the same medium at $4^{\circ} \mathrm{C}$ (Table 4).

The survival pattern for $H$. paragallinarum stored in the different versions of the transport medium held at room temperature were very similar to the results obtained when the samples were stored at $25^{\circ} \mathrm{C}$. As in the previous cases (i.e. storage at $4^{\circ} \mathrm{C}$ and $25^{\circ} \mathrm{C}$ ) the best results were obtained with the medium containing all of the supplements.

The results obtained when $H$. paragallinarum was stored at $37^{\circ} \mathrm{C}$ on the different versions of the medium were more similar to the results obtained when the samples were stored at $4^{\circ} \mathrm{C}$. As in all of the cases the best results were obtained with medium containing all of the supplements. These results were substantially different from the results obtained when the different media were stored at room temperature and at $25^{\circ} \mathrm{C}$. It can be seen from this data that the best survival was obtained in the medium with all of the supplements and viable bacteria were still detected in this medium after 18 days at $37^{\circ} \mathrm{C}$.

To further test the effectiveness of commercial available Amies Transport swabs, samples obtained from Zimbabwe were tested for viability. These isolates were serotyped and found to be serovar C-3. (Bragg 2002).

During transport of samples it is unlikely that a constant temperature can be attained. A trial experiment was therefore conducted with samples transported in different media from Bloemfontein to Cape Town and returned back to Bloemfontein during a 6 -day period. All isolates transported in the different media where found to be viable after this 6-day period (Table 5). 
Transportation of pure cultures of $H$. paragallinarum for serotyping

TABLE 1 Abbreviations of the different transport media evaluated for the transport of $H$. paragallinarum

\begin{tabular}{|l|l|l|l|l|}
\hline Abbreviation & $\begin{array}{l}\text { Tube or } \\
\text { swab }\end{array}$ & $\begin{array}{l}\text { With } \\
\text { charcoal }\end{array}$ & $\begin{array}{l}\text { With } \\
\text { supplements }\end{array}$ & Supplements \\
\hline A/Wc & Tube & Yes & No & None \\
A/-C & Tube & No & No & None \\
A/TS & Swab & No & No & None \\
A/NAD & Tube & No & Yes & 2.5 m $/ \ell$ of a $1 \%$ NAD \\
A/T & Tube & No & Yes & 50 m $\ell / \ell$ oleic-albumin complex (O-A) \\
A/O-A & Tube & No & Yes & 10 m $/ \ell$ heat inactivated chicken serum \\
A/serum & Tube & No & & 2.5 m $\ell / \ell$ of a $1 \%$ NAD \\
A/supp & Tube & & 10 m $\ell / \ell$ thiamine hydrochloride \\
& & & 10 m $\ell / \ell$ heat inactivated chicken serum \\
& & & 50 m $/ \ell$ oleic-albumin complex (O-A) \\
\hline
\end{tabular}

TABLE 2 Growth after revival of $H$. paragallinarum streaked onto plates of Amies Transport Medium with (A/Wc) and without (A/-c) the addition of charcoal after 4 days' incubation at $37^{\circ} \mathrm{C}$

\begin{tabular}{|l|l|l|l|}
\hline Media & Number tested & Number showing growth & Confirmation by PCR \\
\hline A/Wc & 3 & 0 & N/A* \\
A/-C & 3 & 1 & Positive \\
\hline
\end{tabular}

${ }^{*} \mathrm{~N} / \mathrm{A}=$ Not applicable and there were no surviving colonies

TABLE 3 Results obtained when commercially available Amies Transport swabs without charcoal (A/Ts) was used to store $H$. paragallinarum at different temperatures

\begin{tabular}{|c|l|l|l|l|}
\hline \multirow{2}{*}{ Days } & \multicolumn{2}{l|}{ Storage temperature } & Room temperature & $37^{\circ} \mathrm{C}$ \\
\cline { 2 - 5 } & $4^{\circ} \mathrm{C}$ & $25^{\circ} \mathrm{C}$ & $2 / 2$ & $2 / 2$ \\
\hline 4 & $2 / 2$ & $2 / 2$ & $2 / 2$ & $2 / 2$ \\
5 & $2 / 2$ & $2 / 2$ & $2 / 2$ & $2 / 2$ \\
6 & $2 / 2$ & $2 / 2$ & $2 / 2$ & $2 / 2$ \\
7 & $2 / 2$ & $2 / 2$ & $2 / 2$ & $2 / 2$ \\
8 & $2 / 2$ & $1 / 2$ & - & $2 / 2$ \\
9 & $2 / 2$ & - & - & - \\
10 & - & - & - & - \\
11 & - & - & & \\
\hline
\end{tabular}

TABLE 4 Comparison of the maximum survival time in days of $H$. paragallinarum in the different transport media. The figure in brackets is the percentage of isolates surviving on the last day when growth was detected

\begin{tabular}{|l|l|l|l|l|}
\hline \multirow{2}{*}{ Media } & \multicolumn{2}{l|}{ Temperature } & Room temperature & $37{ }^{\circ} \mathrm{C}$ \\
\cline { 2 - 5 } & $4{ }^{\circ} \mathrm{C}$ & $25{ }^{\circ} \mathrm{C}$ & $8(100 \%)$ & $9(100 \%)$ \\
\hline A/TS & $9(100 \%)$ & $8(50 \%)$ & $7(50 \%)$ & $15(100 \%)$ \\
A/NAD & $15(100 \%)$ & $6(50 \%)$ & $6(100 \%)$ & $16(50 \%)$ \\
A/T & $16(50 \%)$ & $6(50 \%)$ & $6(100 \%)$ & $16(100 \%)$ \\
A/O-A & $15(100 \%)$ & $5(100 \%)$ & $7(50 \%)$ & $15(100 \%)$ \\
A/serum & $15(100 \%)$ & $6(100 \%)$ & $8(100 \%)$ & $18(100 \%)$ \\
A/supp. & $18(100 \%)$ & $7(100 \%)$ & & \\
\hline
\end{tabular}


R.R. BRAGG et al.

TABLE 5 Isolation of $H$. paragallinarum from different transport media sent to Cape Town and returned to Bloemfontein in different transport media over a period of 6 days

\begin{tabular}{|l|l|l|}
\hline Media & Number tested & Number positive \\
\hline Transport swabs & 3 & 3 \\
A/NAD & 3 & 3 \\
A/T & 3 & 3 \\
A/A-O & 3 & 3 \\
A/serum & 3 & 3 \\
A/supp & 3 & 3 \\
\hline
\end{tabular}

One of the main objectives of these experiments was to establish a procedure to collect samples from clinically infected chickens from remote areas and the transport of these samples to a laboratory where $H$. paragallinarum can be isolated and serotyped. This was achieved during a transport simulation where samples were sent by postal service from Bloemfontein to Cape Town and returned to Bloemfontein during a 6-day period. Viable samples were obtained from all transport media tested. More importantly, similar results were obtained with samples collected in Zimbabwe and transported to Bloemfontein for further processing; in this case viable $H$. paragallinarum bacteria were isolated, serotyped and found to belong to serovar C-3 (Bragg 2002).

The addition of supplements required for the growth of $H$. paragallinarum into Amies Transport Medium without charcoal increased the storage time of $H$. paragallinarum in media containing full supplementation at $4{ }^{\circ} \mathrm{C}$ and $37^{\circ} \mathrm{C}$. The storage time was not increased when the supplements were added, and the tubes stored at $25^{\circ} \mathrm{C}$ and at room temperature. It is not always possible to ensure that the environmental temperature of the samples can be maintained at $4^{\circ} \mathrm{C}$ for 18 days during transportation, particularly under third world conditions. As $H$. paragallinarum was isolated in commercially available Amies Transport Media without charcoal for up to 8 days with storage at either $25^{\circ} \mathrm{C}$ or at room temperature, it is suggested that this commercially available product be used to transport samples of H. paragallinarum. It was successfully used when samples were transported from Zimbabwe. When temperatures of $4^{\circ} \mathrm{C}$ can be guaranteed, Amies Transport Medium with the full range of supplements will increase the time from 9-18 days that samples can be successfully transported.

\section{REFERENCES}

BIBERSTEIN, E.L. \& WHITE, D.C. 1969 A proposal for the establishment of two new Haemophilus species. Journal of Medical Microbiology, 2:75-78.

BLACKALL, P.J. \& REID, G.G. 1982. Further characterization of Haemophilus paragallinarum and Haemophilus avium. Veterinary Microbiology, 7:359-367.

BLACKALL, P.J., EAVERS, E.L. \& ROGERS, D.G. 1990a. Proposal of a new serovar and altered nomenclature of Haemophilus paragallinarum in the Kume haemagglutinin scheme. Journal of Clinical Microbiology, 135:469-474.

BLACKALL, P.J., EAVERS, E.L. \& AUS, G. 1990b. Serotyping of Haemophilus paragallinarum by the Page scheme: comparison of the use of agglutination and hemagglutinationinhibition tests. Avian Diseases, 34:643-645.

BRAGG, R.R. 2002. Isolation of serovar C-3 Haemophilus paragallinarum from Zimbabwe: A further indication of the need for local vaccines against infectious coryza. Onderstepoort Journal of Veterinary Research, 69:129-132.

CHEN, X., MIFLIN, J.K., ZHANG, P. \& BLACKALL, P.J. 1996. Development and application of DNA probes and PCR tests for Haemophilus paragallinarum. Avian Diseases, 40:398407.

DE BLIECK, L. 1932. A haemoglobinophilic bacterium as the cause of contagious catarrh of the fowl. Veterinary Journal, 88:9-13.

HINZ, K-H., 1973. Differentiation of Haemophilus species from fowls. 1. Cultural and biochemical studies. Avian Pathology, 2:211-229.

KUME, K., SAWATA, A. \& NAKASE, Y. 1980. Immunological relationship between Page's and Sawata's serotype strains of Haemophilus paragallinarum. The Veterinary Record, 41: 757-760.

KUME, K., SAWATA, A., NAKASE, Y. \& MATSUMOTO, M. 1983. Serologicalclassification of Haemophilus paragallinarum with a haemagglutinin system. Journal of Clinical Microbiology, 17:958-964.

MIFLIN, J.K., CHEN, X., BRAGG, R.R., WELGEMOED, J.M., GREYLING, JM., HORNER, R.F. \& BLACKALL, P.J. 1999. Confirmation that PCR can be used to identify NAD-dependent and NAD-independent Haemophilus paragallinarum isolates. Onderstepoort Journal of Veterinary Research, 66: 55-57.

PAGE, L.A. 1962. Haemophilus infection in chickens. 1. characteristics of 12 Haemophilus isolates recovered from diseases chickens. American Journal of Veterinary Research, 23:85-95.

REID, G.G. \& BLACKALL, P.J. 1984. Pathogenicity of Australian isolates of Haemophilus paragallinarum and Haemophilus avium in chickens. Veterinary Microbiology, 9:77-82. 
Transportation of pure cultures of $H$. paragallinarum for serotyping

RIMLER, R.B., DAVIES, R.B. \& PAGE, R.K. 1977. Infectious coryza: cross protection studies, using seven strains of Haemophilus paragallinarum. American Journal of Veterinary Research, 38:1587-1589.
SAWATA, A., KUME, K. \& NAKASE, Y. 1980. Biological and serological relationships between Page's and Sawata's serotyping of Haemophilus paragallinarum. American Journal of Veterinary Research, 41:1901-1904. 